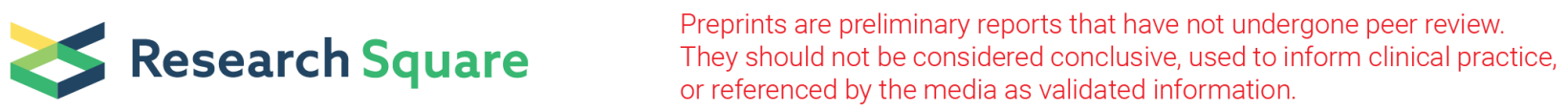

\title{
Evaluation of Inhibitory Activity, Purification and X-Ray Crystallography of Alpha-Amylase Inhibitor from Phaseolus Vulgaris Cultivars of Uttarakhand
}

\author{
Ravinder Singh \\ Guru Nanak Dev University \\ Anoop Kumar Dobriyal \\ Hemwati Nandan Bahuguna Garhwal University \\ Rattan Deep Singh \\ University Phagwara, India \\ Patricio De los Rios-Escalante ( $\nabla$ prios@uct.cl) \\ Temuco Catholic University
}

\section{Research Article}

Keywords: Alpha-amylase inhibitor, Phaseolus vulgaris, Inhibitory activity, PAGE, Starch blocking activity, X-ray Crystallography

Posted Date: February 10th, 2021

DOI: https://doi.org/10.21203/rs.3.rs-154559/v1

License: () (1) This work is licensed under a Creative Commons Attribution 4.0 International License. Read Full License 


\section{Abstract}

The present work is based on analysis of inhibitory activity of alpha-amylase inhibitor in selected cultivars of Phaseolus vulgaris of Uttarakhand. Fifteen samples were assessed for inhibitory activity of alpha-amylase inhibitor. Significant variations were found in different cultivars. Crude extract of alphaamylase inhibitor from sample PUR (Purola) have shown maximum inhibitory activity $(70.2 \pm 0.84)$. Crude extract of all the cultivars have shown considerable variations in inhibitory activity in the temperature ranging from $20^{\circ} \mathrm{C}$ to $100^{\circ} \mathrm{C}$. Based on inhibitory activity and heat stability profile, the alpha amylase inhibitor was purified from PUR cultivar. The purified inhibitor was found to be stable even at $90^{\circ} \mathrm{C}$ with an inhibitory activity of $97.20 \pm 0.09$. The molecular weight of purified inhibitor on Native PAGE (Polyacrylamide gel electrophoresis) was found to be $31 \mathrm{kd}$, consisting of two subunits of $17 \mathrm{kd}$ and $14 \mathrm{kd}$ on SDSPAGE.

\section{Introduction}

Plant seeds produce a variety of proteinaceous inhibitors of proteases and amylases. These inhibitors are characterized on the basis of sequences similarity and class of enzyme they inhibited ${ }^{1}$. Seed of common bean (Phaseolus vulgaris L.) contain certain inhibitors for digestive enzyme a-amylase. The amylase inhibitor does not inhibit the activity of plant, fungal and bacterial a- amylases, but inhibits the activity in mammals and some insects ${ }^{2}$. The $a-a m y l a s e$ inhibitor strongly inhibits the larval midgut a-amylase activities of adzuki bean weevil (Collasobruchus chinesis L.) and Cowpea weevil (Collasobruchus maculatus), non-pest species of common bean ${ }^{3}$. The amylase inhibitors can be classified according to their tertiary structure in six different classes, namely lectin like, knottin like, cereal type, kunitz like, $y$-purothinin like and thaumatin like ${ }^{4}$. Phaseolus vulgaris a-amylase inhibitors are also known as starch blockers and has been developed into more effective control agents for diabetes and obesity 5 .

A starch blocker is a substance that interferes with the breakdown of starch leading to reduced digestibility such that energy derived from the starch is reduced or rate of body absorption of energy in the form of glucose is reduced ${ }^{6}$. Several amylase inhibitors drugs (acarbose, voglibose) are in use for diabetic patients, often in conjugation with insulin ${ }^{7}$. Although the biochemical properties of legume a-amylase inhibitor have been studied for over 20 years some discrepancies dealing with their physico-chemical and functional properties have been frequently reported. In addition, only a little is known on their structural features, and their inhibition mechanism remains to be studied in details. Amylase inhibitor has been shown to have nutraceutical properties as well ${ }^{8}$. Since Uttarakhand is a rich repository of beans as more than 50 cultivars have been found, therefore the present study was undertaken to evaluate the starch blocking activity i.e. amylase inhibitor activity, heat stability of alpha-amylase inhibitor in selected cultivars, purification and crystallographic analysis of alpha-amylase inhibitor.

\section{Results And Discussion}

Assessment of starch blocking activity of a-amylase inhibitor: Alpha-amylase inhibitor protein inhibits the a-amylase enzyme and interferes in digestion of starch. Therefore, inhibitory activity of a-amylase inhibitor in selected cultivars can be used as a measure of starch blocking activity. Inhibition of pancreatic amylase was observed in all the seed samples thus showing the presence of a- amylase inhibitor (Table 2). The cultivars were found to differ significantly in inhibitory activity. The maximum inhibitory activity was found to occur in sample PUR (70.2 $\pm 0.84 \%)$ and minimum in sample DUN ( $39.43 \pm 0.47 \%)$. Sample PUR and MUN-2 have not shown a significant difference in inhibitory activity, similarly sample MAJ and RUD have nearly similar inhibitory activity, whereas all other cultivars are found to differ significantly in inhibitory activity of amylase inhibitor. Research into the mechanism of the Phaseolus vulgaris $a$-amylase inhibitor action shows that the inhibitor is effective in preventing starch digestion by restricting access to active site of the enzyme. The molecular-level binding of the action of the amylase inhibitor on human pancreatic amylase and PPA was reviewed in detail ${ }^{9}$. The study reveals that during inhibition, the components of inhibitor molecule play an important role in this mechanism. The main components that participate in the mechanism include two loops of the inhibitor made up of residues 20-45 and 172-19010, the amylase domains A/B and the active site non-loop residues (Asp197, Glu233, Asp300 and Arg74) in human pancreatic amylase ${ }^{11}$

Effect of temperature on a-amylase inhibitor: Significant variations in inhibitory activity were found between all the cultivars. The inhibitory activity of cultivars increases upto 60 or $70^{\circ} \mathrm{C}$, afterwards there is decrease in the values of inhibitory activity. Sample DWA, MAJ, ALM, RAM and MUN-2 has shown maximum inhibitory activity at $50^{\circ} \mathrm{C}$ and above this temperature the inhibitory activity decreases. Similarly, sample CHM, DUN, DHA, JOSH, TAP, MUN-1, MAJ and CHK have shown an increase in activity upto $60^{\circ} \mathrm{C}$ and then there is decrease in activity with an increase in temperature (Table 3 ). The minimum inhibitory activity at $20^{\circ} \mathrm{C}$ was shown by sample DUN (36.45 $\left.\pm 0.65 \%\right)$ and maximum by sample PUR $(71.34 \pm 0.42 \%)$ than other cultivars. On the other hand, at $100^{\circ} \mathrm{C}$ the minimum inhibitory activity was shown by sample DWA $(25.22 \pm 0.40 \%)$ and maximum by sample PUR $(70.23 \pm 0.28 \%)$. Out of the fifteen cultivars, sample PUR has shown a consistent stability in amylase inhibitor activity even at $100^{\circ} \mathrm{C}$ (Table 5). Heat stability of a-amylase inhibitor has been shown by many studies. The inhibitor has been found to be stable at a temperature range of $40-90^{\circ} \mathrm{C}^{12,13}$. The inhibitor is completely inactivated at $100^{\circ} \mathrm{C}$ by boiling for 10 $\min ^{8}$.

Purification and Molecular weight determination of a-amylase inhibitor: Based upon the inhibitor activity and effect of temperature on crude extract of amylase inhibitor in selected cultivars, purification of amylase inhibitor was done from sample PUR. Purification was done by ammonium salt precipitation (80-90\%) followed by dialysis and gel-filtration chromatography using Sephadex G-50 column. The fractions were collected at constant flow rate and were assayed for protein estimation (\%) and specific activity (\%). The specific activity was found to increase after each purification procedure (Table 4). The fractions eluted from sephadex column were analysed for inhibitory activity against PPA (Fig. 1) The purified fraction of sample PUR on SDS-PAGE was found to resolve into two bands of molecular weight of 14 and 17kd (Fig. 2). These bands may be due to denaturation of pure amylase inhibitor into two subunits. Native PAGE of purified inhibitor from sample-PUR has shown a single band corresponding to molecular weight of 31kd (Fig. 3). The results obtained in 
present study were similar with literature references ${ }^{8}$, where the molecular weight of a-amylase inhibitor from Vigna sublobata was found to be $14 \mathrm{kd}$ on SDSPAGE.

X-ray crystallography of purified a-amylase inhibitor: Crystals of purified enzymes from PUR cultivars were obtained by hanging drop methods and was found to differ in shape, wavelength, and space groups and in solvent content. X-ray analysis of sample- PUR was purified to homogeneity and crystallized at $293 \mathrm{~K}$ (Fig. 4). The crystals diffracted beyond $1.0 \AA$ resolution using synchrotron single beam x-ray crystallography. The crystal belongs to the monoclinic space group $\mathrm{P} 2{ }_{1} 2{ }_{1}$, with Unit-cell parameters $\left(A^{\circ}\right) a=74.56, b=60.45, c=64.40$. Percent solvent content was $42.05 \%$. Similar type of crystallography has been reported by literature references ${ }^{14}$ in bifunctional amylase/subtilisin inhibitor purified from rice in which the crystal was found to be monoclinic with unit cell parameters of $a=79.99, b=62.95, c=66.70 \AA$.

As conclusion, the present work describes the comparative analysis of alpha amylase inhibitor activity in selected cultivars of kidney beans and its purification from sample PUR. The present study revealed that the inhibitory activity of plant alpha- amylase inhibitor against mammalian amylases could cause a marked decrease in the availability of digested starch. This could suggest a potential in the prevention and treatment of diabetes and nutritional problems, which result in obesity. Based on the results of this study, the a-amylase inhibitors from Phaseolus vulgaris may have potential in the prevention and therapy of obesity and diabetes.

\section{Materials And Methods}

Seed samples: Seeds of Phaseolus vulgaris have been collected from different geographical locations of Uttarakhand. Fifteen cultivars showing variation in seed coat colour, size and shape were selected. The seeds were authenticated and deposited in National Bureau of Plant and Genetic Research, New Delhi, India (Table 1).

Chemicals and Reagents: Sephadex G-50, PPA (Porcine pancreatic amylase) were purchased from Sigma (India). Protein markers were purchased from Genei (India) and others required chemicals from Himedia (India).

Crude extract Preparation: The extraction of seed proteins from seed flour was done according to the method described by literature ${ }^{3} .100$ mg of finely grounded seed flour was taken, homogenised in extraction buffer and was incubated at $4^{\circ} \mathrm{C}$ for $1 \mathrm{hr}$. The homogenate was then centrifuged at $15000 \mathrm{rpm}$ for $15 \mathrm{~min}$ at $4^{\circ} \mathrm{C}$. The supernatant was collected and stored in aliquots at $-20^{\circ} \mathrm{C}$ for further analysis. The protein content was measured by method described by Bradford $^{15}$

Amylase inhibitory activity: The amylase inhibitory activity was determined according to literature descriptions ${ }^{8}$ with some modifications. A soluble starch solution $(0.4 \mathrm{ml}, 1 \% \mathrm{w} / \mathrm{v})$ was made in $80 \mathrm{mM}$ phosphate buffer $(\mathrm{pH}=6.9)$ and a solution of PPA $(0.2 \mathrm{ml}, 0.001 \% \mathrm{w} / \mathrm{v})$ in $20 \mathrm{mM}$ acetate buffer $(\mathrm{pH}-4.5$, containing $20 \mathrm{mM} \mathrm{CaCl}_{2}$ and $10 \mathrm{mM} \mathrm{NaCl}$ ) was added into it and then incubated for $15 \mathrm{~min}$ at $37^{\circ} \mathrm{C}$. The reaction was stopped by addition of $0.8 \mathrm{ml}$ of Dinitrosalicylic acid reagent (1 gm DNS, $200 \mathrm{mg}$ crystalline phenol and $50 \mathrm{mg}$ of sodium sulphite dissolved in $1 \% \mathrm{NaOH}$ ). The contents were heated in a boiling water bath for $5 \mathrm{~min}$, and after cooling it was diluted with $4 \mathrm{ml}$ of water. Absorbance of the mixture was read at $540 \mathrm{~nm}$ against blank prepared without using PPA. Amount of maltose produced was calculated from standard curve of maltose. The above method was also used to describe a-amylase inhibitor activity but PPA solution and purified inhibitor solutions $(0.2 \mathrm{ml})$ were pre-incubated for $15 \mathrm{~min}$ before addition of soluble starch solution. Alpha-amylase inhibitory activity was calculated according to equation shown below:

Inhibitory activity $(\%)=\left[M_{0}-M_{i} / M_{0}\right] \times 100$

Where, $M_{0}$ and $M_{i}$ are amount of maltose $(\mathrm{mg} / \mathrm{ml})$ produced in absence and presence of inhibitor respectively, under the same conditions.

Heat stability: Heat stability was evaluated from literature descriptions ${ }^{13}$. Both the extracts (crude and purified) were incubated in a water bath at different temperatures ranges from $20^{\circ} \mathrm{C}$ to $100^{\circ} \mathrm{C}$ with the difference of $10^{\circ} \mathrm{C}$, after that amylase inhibitory activity was calculated

Purification of a-amylase inhibitor: Ammonium sulphate precipitation (80-100\% saturation) of the crude protein extract was performed at $4^{\circ} \mathrm{C}$. The precipitate was dissolved in $10 \mathrm{mM}$ Tris- $\mathrm{HCl}$ and was dialyzed against buffer in batches. The dialyzed material was stored at $-20^{\circ} \mathrm{C}$ till further analysis. The a-amylase inhibitor was fractionated by repeated size exclusion chromatography on a Sephadex G-50 column (26x1.2 cm).

Molecular identification: The polypeptides in the samples were fractionated using SDS-PAGE (15\%) under reducing conditions and Native PAGE. The molecular weight of purified inhibitor was determined by using medium range protein marker (14.3-97.4 kd).

X-ray Crystallography: The purified protein sample was re-dissolved at a concentration of $10 \mathrm{mg} / \mathrm{ml}$ in double-deionised water. Crystallization was performed using VDX48 plates by the hanging-drop vapour-diffusion method.

Statistical analysis: Each sample was analysed in triplicates and the values were averaged. Data was assessed by analysis of variance (ANOVA), previous verification of normal distribution and variance homogeneity ${ }^{16}$ and mean comparison was done by using Duncan's multiple range test using software $\mathrm{R}^{17}$

\section{Declarations}

\section{Funding}

The study was founded by Post Graduate Institute of Medical Sciences and Research and project MECESUP UCT 0804. 


\section{Conflict of interest}

The authors declare that they have no conflict of interest.

\section{Ethical approval}

There is no ethical issue concerning this article

\section{Compliance with ethical standards}

Ethical approval: All institutional guidelines for the care. No animals have been used in current research work and therefore no ethical permission is required for the same.

Field study: Permits and approval of field or observational studies have been obtained by the authors.

Author Contribution statement: R.S., A.K.D. R.D.S., did chemical analysis, data analysis and redact the manuscript, PDE, collaborate in manuscript redaction.

\section{References}

1. Marina, C. et al. A \& Ramos-Duarte 2019. Plant Serine Protease Inhibitors: Biotechnology Application in Agriculture and Molecular Farming. International journal of molecular sciences $20,1345,1-21$.

2. Bahareh, R., Ghadamyari, M., Imani, S. \& Hosseininaveh, V. \& Ahadiyat, A. 2016. Purification and characterization of a-amylase in Moroccan locust, Dociostaurus maroccanus Thunberg (Orthoptera: Acrididae) and its inhibition by inhibitors from Phaseolus vulgaris $\mathrm{L}$ Toxins reviews, 35, 90-97. https:// doi.org/10.1080/15569543.2016.1207190

3. Neeraj, W., Parag, G., Anuradha, A., Gaurav, S. \& „„ \& Bio-insecticidal potential of amylase inhibitors. BioMedRx. 1, 449-458 (2013).

4. Solanki, D. S. et al. Purification and characterization of a novel thermostable antifungal protein with chitinase activity from mung bean. Journal of Environmental Biology. 39, 406-412 https://doi.org/10.22438/jeb/39/3/MRN-623 (2018).

5. Zhang, S. H. A., George, A. C. \& Jonathan, C. A. Max Bloc® Carb Blocker from Phaseolus Vulgaris with Ultra-high a-Amylase Inhibitory Activity for Glycemic Control and Weight Management. Journal of Nutrition \& Food Science. 2, 1-8 (2020).

6. Mrinal, S., Rotemi, E. A. \& Tejpal, D. Plant food anti-nutritional factors and their reduction strategies: an overview Food Production. Processing and Nutrition. 2, 1-14 (2020). https://doi.org/10.1186/s43014-020-0020-5

7. Harish, C., Rodda, T., Sandhya \& Swetha, P. Evaluation of a - amylase inhibitory activity of some clinically used drugs. International journal of pharmaceutical sciences and research. 5, 1843-1846 https://doi.org/10.13040/ (2019).

8. Yang, H., Yingying Zhu, Yue \& Gao Guixing, R. 2016. Comparisons of phaseolin type and a-amylase inhibitor in common bean (Phaseolus vulgaris L.) in China. The crop Journal 4, 68-72. https://doi.org/10.1016/j.cj.2015.09.002

9. Jean-Luc Da Lag. The amylases of insects. International J. of Insect Science. 10, 1-14 https://doi.org/10.1177/1179543318804783 (2020).

10. Mohammed Auwal, I., James, D. H., Neil, A. K. \& Md Shahidul Islam.2017. a-Glucosidase and a-amylase inhibitory compounds from three african medicinal plants: an enzyme inhibition kinetics approach. Natural products Communications, 12,1125-1128.

11. Kouiekelo, R., Dessaeux, V., Moreau, Y., Marchis-Mouren, G. \& Santimone, M. Mechanism of porcine pancreatic a-amylase inhibition of amylose and maltopentose hydrolysis by a, $\beta$-and Y-cyclodextrins. European Journal of Biochemistry. 268, 841-848 (2001). doi: 10.1046/j.1432-1327.2001.01950.

12. Kazumi, N. et al. 2018. Suppressive effect of the a-amylase inhibitor albumin from buckwheat (fagopyrum esculentum moench) on postprandial hyperglycaemia. Nutrients, 10, 1-12. doi: 10.3390/nu10101503

13. Irushika, T., Fernando; Kumudu, I., Perera, S., Ramiah, B. P. A. \& S Heat stability of the in vitro inhibitory effect of spices on lipase, amylase, and glucosidase enzymes. Food science and nutrition. 7, 425-432 (2019).

14. Lin, Y. H. et al. Purification, crystallization and preliminary X-ray crystallographic analysis of rice bifunctional a-amylase/subtilisin inhibitor from Oryza sativa. Acta Crystallogr. A. 62, 743-745 https://doi.org/10.1107/S1744309106023335 (2006).

15. Vivek \& Donthula, S. 2013. Evaluation of Protein Content among Sprouted and Un-Sprouted Seeds of Selected Pulses. Helix, 4, 374-377.

16. Eva, O. \& Oskar, O. Methodology and Application of One-way ANOVA. American Journal of Mechanical Engineering,. 1, 256-261 https://doi.org/10.12691/ajme-1-7-21 (2013).

17. R Development Core Team. 2009. R: A Language and Environment for Statistical Computing. R version 3.6.1. The R Foundation for Statistical Computing, Vienna, Austria. URL: https://www.R-project.org/.

\section{Tables}

Table 1. List of Phaseolus vulgaris cultivars collected from different provenances of Uttarakhand. 


\begin{tabular}{|lll|}
\hline Code & Location & Accession No. \\
\hline PUR & Purola & IC-569208 \\
DHA & Dhankot & IC-569215 \\
\hline TAP & Tapovan & IC-569214 \\
\hline MUN-1 & Munsiyari & IC-569213 \\
\hline DUN & Dunagiri & IC-582575 \\
\hline DWA & Dwarahaat & IC-582576 \\
\hline HAR & Harsil & IC-569211 \\
\hline JOSH & Joshimath & IC-582574 \\
\hline CHM & Chamba & IC-569209 \\
\hline MAJ & Majkhali & IC-569212 \\
\hline CHK & Chakrata & IC-582573 \\
\hline MUN-2 & Munsiyari & IC-569210 \\
\hline RUD & Rudraprayag & IC-582577 \\
\hline ALM & Almora & IC-582578 \\
\hline RAM & Ramgarh & IC-582572 \\
\hline
\end{tabular}

Table 2. Inhibitory activity (\% inhibition) of alpha-amylase inhibitor in Cultivars of Phaseolus vulgaris

\begin{tabular}{|lll|}
\hline S.no & Cultivars & Inhibitory Activity (\%) \\
\hline 1 & DWA & $45.23^{\mathrm{a}} \pm 0.23$ \\
\hline 2 & HAR & $52.69^{\mathrm{b}} \pm 0.56$ \\
3 & CHM & $57.01^{\mathrm{g}} \pm 0.78$ \\
\hline 4 & DUN & $39.43^{\mathrm{e}} \pm 0.47$ \\
\hline 5 & PUR & $70.2^{\mathrm{c}} \pm 0.84$ \\
\hline 6 & DHA & $68.56^{\mathrm{d}} \pm 0.65$ \\
\hline 7 & JOSH & $65.23^{\mathrm{f}} \pm 0.05$ \\
\hline 8 & MUN-1 & $55.92^{\mathrm{k}} \pm 0.15$ \\
\hline 9 & TAP & $56.17^{\mathrm{h}} \pm 0.10$ \\
\hline 10 & MAJ & $60.21^{\mathrm{k}} \pm 0.08$ \\
\hline 11 & CHK & $58.45^{\mathrm{g}} \pm 0.36$ \\
\hline 12 & ALM & $64.56^{\mathrm{f}} \pm 0.18$ \\
\hline 13 & RUD & $61.58^{\mathrm{k}} \pm 0.53$ \\
\hline 14 & RAM & $66.34^{\mathrm{f}} \pm 0.46$ \\
\hline 15 & MUN-2 & $69.57^{\mathrm{dc}} \pm 0.18$ \\
\hline
\end{tabular}

Means in a column with different letters are significantly different $(p<0.05: n=3)$

Table 3. Effect of temperature on inhibitory activity of alpha-amylase inhibitor. 


\begin{tabular}{|c|c|c|c|c|c|c|c|c|c|c|}
\hline Cultivars & Inhibitor & 20 & 30 & 40 & 50 & 60 & 70 & 80 & 90 & 11 \\
\hline DWA & \multirow{13}{*}{$\begin{array}{l}\text { Activity } \\
(\%)\end{array}$} & $46.23^{a} \pm 0.80$ & $50.34^{\mathrm{b}} \pm 0.17$ & $52.33^{\mathrm{cb}} \pm 0.28$ & $56.43^{d} \pm 0.56$ & $55.87^{e} \pm 0.70$ & $50.22^{b} \pm 0.20$ & $40.34^{f} \pm 0.32$ & $36.34^{\mathrm{g}} \pm 0.15$ & $2 !$ \\
\hline HAR & & $47.23^{a} \pm 0.19$ & $53.34^{b} \pm 0.61$ & $56.75^{\complement} \pm 0.79$ & $60.45^{\mathrm{d}} \pm 0.69$ & $64.23^{\mathrm{e}} \pm 0.25$ & $68.34^{f} \pm 0.48$ & $62.14^{\mathrm{g}} \pm 0.77$ & $56.77^{c} \pm 0.11$ & 51 \\
\hline $\mathrm{CHM}$ & & $52.43^{\mathrm{a}} \pm 0.46$ & $56.71^{b} \pm 0.22$ & $60.34^{\mathrm{C}} \pm 0.18$ & $62.56^{\mathrm{d}} \pm 0.08$ & $68.45^{e} \pm 0.81$ & $64.56^{f} \pm 0.38$ & $60.35^{c} \pm 0.93$ & $57.25^{9} \pm 0.79$ & 51 \\
\hline DUN & & $36.45^{a} \pm 0.65$ & $40.56^{b} \pm 0.47$ & $45.67^{c} \pm 0.37$ & $49.11^{\mathrm{dc}} \pm 0.06$ & $53.78^{d} \pm 0.14$ & $50.24^{d} \pm 0.24$ & $47.88^{\mathrm{c}} \pm 0.13$ & $42.19^{b} \pm 0.12$ & 34 \\
\hline PUR & & $71.34^{\mathrm{a}} \pm 0.42$ & $67.82^{\mathrm{b}} \pm 0.40$ & $68.24^{d} \pm 0.50$ & $71.34^{\mathrm{ca}} \pm 0.36$ & $71.64^{c} \pm 0.29$ & $74.45^{e} \pm 0.53$ & $75.97^{f} \pm 0.66$ & $75.23^{\mathrm{e}} \pm 0.22$ & 71 \\
\hline DHA & & $67.64^{a} \pm 0.07$ & $67.45^{a b} \pm 0.39$ & $69.67^{b} \pm 0.67$ & $70.23^{d} \pm 0.38$ & $71.64^{e} \pm 0.67$ & $63.45^{f} \pm 0.25$ & $61.63^{g} \pm 0.31$ & $55.56^{\mathrm{h}} \pm 0.86$ & 51 \\
\hline JOSH & & $67.04^{a} \pm 0.65$ & $69.76^{b} \pm 0.56$ & $71.45^{\mathrm{c}} \pm 0.49$ & $72.23^{\mathrm{c}} \pm 0.38$ & $71.23^{b} \pm 0.96$ & $69.16^{c} \pm 0.24$ & $68.53^{b} \pm 0.69$ & $66.23^{a k_{ \pm}} \pm .2$ & $6 !$ \\
\hline TAP & & $57.62^{\mathrm{a}} \pm 0.02$ & $57.40^{\mathrm{ac}} \pm 0.74$ & $59.63^{d} \pm 0.55$ & $62.43^{f} \pm 0.41$ & $61.23^{f} \pm 0.18$ & $58.45^{\mathrm{adc}} \pm 0.20$ & $54.12^{\mathrm{g}} \pm 0.47$ & $50.62^{h} \pm 0.18$ & $4 !$ \\
\hline MUN-1 & & $56.52^{\mathrm{a}} \pm 0.61$ & $56.87^{b} \pm 0.06$ & $58.62^{c} \pm 0.60$ & $60.45^{\mathrm{c}} \pm 0.52$ & $61.72^{d} \pm 0.24$ & $58.23^{b} \pm 0.27$ & $52.45^{\mathrm{e}} \pm 0.81$ & $49.25^{f} \pm 0.93$ & 46 \\
\hline MAJ & & $60.41^{\mathrm{a}} \pm 0.18$ & $60.55^{\mathrm{a}} \pm 0.10$ & $67.22^{b} \pm 0.48$ & $69.13^{\mathrm{c}} \pm 0.20$ & $65.18^{d} \pm 0.05$ & $62.38^{\mathrm{e}} \pm 0.18$ & $51.87^{f} \pm 0.11$ & $42.14^{\mathrm{g}} \pm 0.14$ & 3\{ \\
\hline $\mathrm{CHK}$ & & $57.12^{\mathrm{a}} \pm 0.14$ & $60.14^{b} \pm 0.20$ & $62.23^{c} \pm 0.08$ & $65.18^{d} \pm 0.10$ & $67.25^{e} \pm 0.45$ & $63.30^{c} \pm 0.23$ & $60.12^{\mathrm{b}} \pm 0.43$ & $58.55^{\mathrm{a}} \pm 0.80$ & $5:$ \\
\hline ALM & & $65.02^{a} \pm 0.67$ & $67.34^{\mathrm{b}} \pm 0.14$ & $69.24^{\mathrm{C}} \pm 0.45$ & $72.67^{d} \pm 0.78$ & $70.92^{e_{ \pm}} \pm 0.34$ & $68.14^{b} \pm 0.56$ & $64.36^{a} \pm 0.77$ & $62.08^{f} \pm 0.29$ & $5 t$ \\
\hline RUD & & $60.34^{\mathrm{a}} \pm 0.46$ & $61.86^{b} \pm 0.24$ & $67.98^{\mathrm{C}} \pm 0.04$ & $70.24^{d} \pm 0.85$ & $70.17^{d} \pm 0.48$ & $68.34^{\mathrm{e}} \pm 0.37$ & $64.22^{f} \pm 0.28$ & $60.56^{\mathrm{a}} \pm 0.40$ & $5 t$ \\
\hline
\end{tabular}

Table 4. Purification of alpha-amylase inhibitor from cultivar-PUR

\begin{tabular}{|lllll|}
\hline Sample & Inhibitory activity (\%) & Protein content (\%) & Specific activity (\%) & Fold Purification \\
\hline Crude extract & 70.67 & 18.2 & 3.88 & 1.0 \\
\hline Amm. ppt. (80-90\%) & 80.45 & 10.56 & 7.60 & 2.0 \\
Sephadex G-50 & 94.25 & 7.36 & 12.8 & 3.3 \\
\hline
\end{tabular}

Table 5. Effect of temperature on purified a-amylase inhibitor from cultivar PUR

\begin{tabular}{|ll|}
\hline Temperature $\left({ }^{0} \mathrm{C}\right)$ & Inhibitory activity $(\%)$ \\
20 & $94.30^{\mathrm{a}} \pm 0.55$ \\
30 & $94.88^{\mathrm{a}} \pm 0.34$ \\
40 & $95.67^{\mathrm{ca}} \pm 0.20$ \\
50 & $96.34^{\mathrm{d}} \pm 0.15$ \\
\hline 60 & $97.56^{\mathrm{e}} \pm 0.85$ \\
\hline 70 & $98.56^{\mathrm{g}} \pm 0.72$ \\
\hline 80 & $98.23^{\mathrm{g}} \pm 0.03$ \\
\hline 100 & $97.20^{\mathrm{eg}} \pm 0.09$ \\
\hline
\end{tabular}

Means in a column with different letters are significantly different $(p<0.05: n=3)$.

\section{Figures}




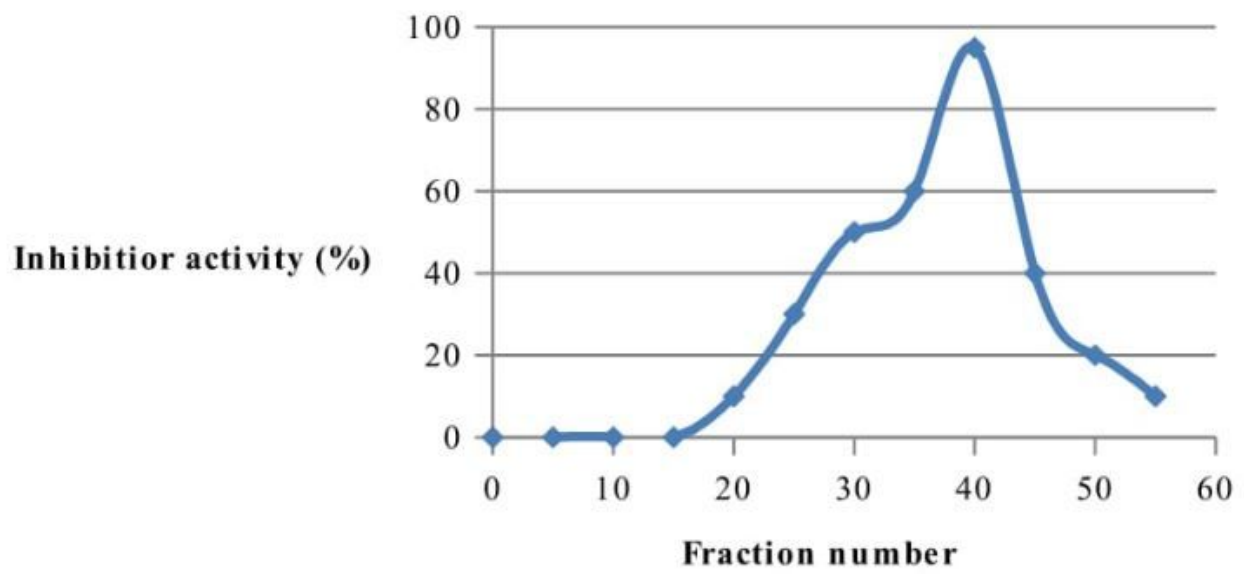

Figure 1

Inhibitory activity of alpha-amylase inhibitor from the fractions eluted from the column. Each fraction (3ml) were pooled and measured for amylase inhibitor activity against PPA.

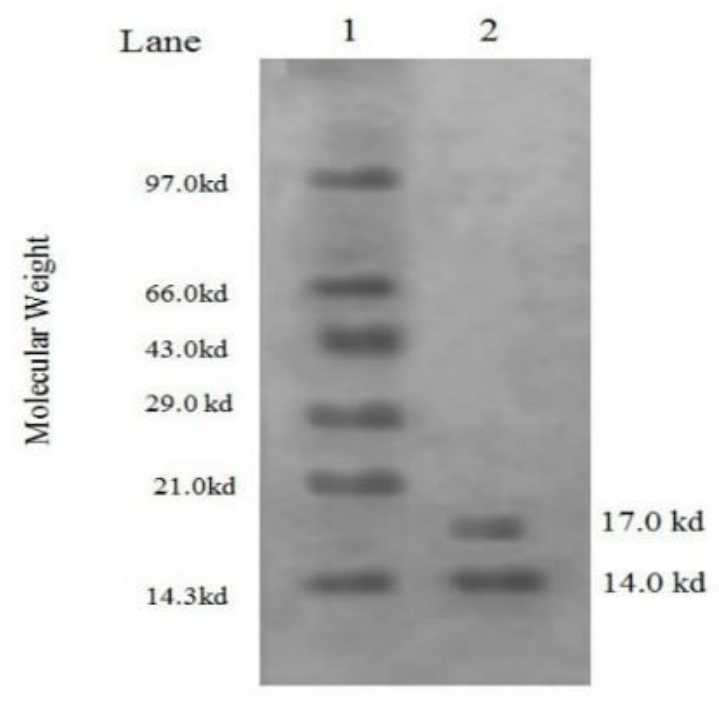

Lane 1- Medium Range Protein Marker (14.3-97.0 kd)

Lane 2- Purified $\alpha$-amylase inhibitor from cultivar PUR

Figure 2

SDS-Page Analysis of Purified a - Amylase Inhibitor from Cultivar-PUR 


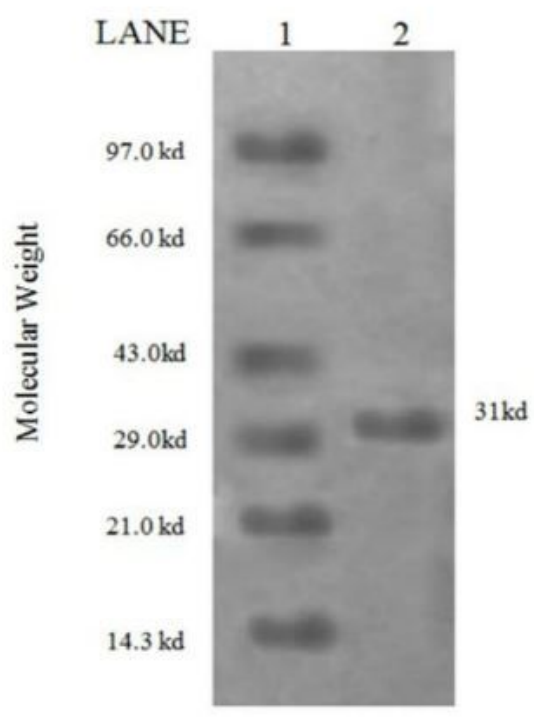

Lane 1- Medium Range Protein Marker (14.3-97.0 kd)

Lane 2- Purified $\alpha$-amylase inhibitor from cultivar PUR

Figure 3

Native Page Analysis of purified a- amylase inhibitor from Cultivar PUR

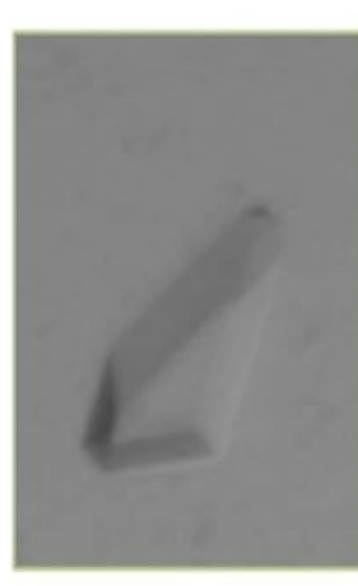

Values in parentheses are for the highest resolution shell $\left(1.87-1.81 \mathrm{~A}{ }^{\circ}\right)$

Wavelength $\left(\mathrm{A}^{\circ}\right) 1.00$

Temperature $\left({ }^{\circ} \mathrm{C}\right) 100$

Resolution range $\left(\mathrm{A}^{\circ}\right)$ 30.0-1.81

Space group $\mathrm{P}_{1} 2_{1} 2$

Unit-cell parameters $\left(A^{\circ}\right) a=74.56, b=60.45, c=64.40$

Unique reflections 31206

Completeness (\%) 98.5

Average redundancy $4.7 \mathrm{~s}$

Mosaicity $\left(^{\circ}\right) 0.414$

Matthews coefficient $\left(\mathrm{A}^{03} \mathrm{Da}^{-1}\right) 2.85$

Solvent content (\%) 42.05

Figure 4

X-ray crystallographic analysis of purified inhibitor from Cultivar-PUR 